\title{
Evaluating the Development Potentials of Agri Sites for Tourism: The Case of Tigaon, Province of Camarines Sur, Philippines
}

By Jossie B. Romero

Partido State University

Abstract- The study aims to evaluate the potential and prospects of agritourism sites in Barangays Tinawagan and Libod, Tigaon, Camarines Sur through Community-Based Participatory Action Research approach. The result of the study will serve as baseline information to develop community-managed agritourism trek in the area to help the community uplift the socio-economic status. The study focuses on classifying the potential agritourism sites from the point of origin, accessibility, mode of transportation and side attractions, evaluating the environment and surroundings of the locality and other services. The Tourism Assessment Process (Linking Communities Tourism and Conversation) model was utilized through focused group discussions, ocular and site visit, and oral interview were considered in gathering the data. The gathered data were treated using descriptive statistics.

Keywords: agritourism, development, tourism potentials, community based participatory action research.

GJMBR-F Classification: JEL Code: L83

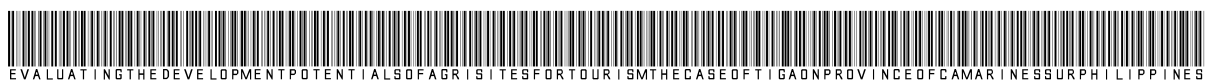

Strictly as per the compliance and regulations of:

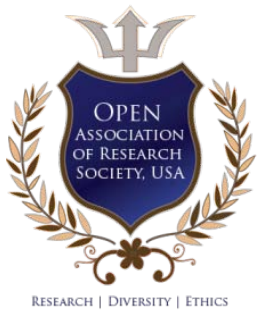

(c) 2020. Jossie B. Romero. This is a research/review paper, distributed under the terms of the Creative Commons AttributionNoncommercial 3.0 Unported License http://creativecommons.org/licenses/by-nc/3.0/), permitting all non-commercial use, distribution, and reproduction in any medium, provided the original work is properly cited. 


\title{
Evaluating the Development Potentials of Agri Sites for Tourism: The Case of Tigaon, Province of Camarines Sur, Philippines
}

\author{
Jossie B. Romero
}

Abstract- The study aims to evaluate the potential and prospects of agritourism sites in Barangays Tinawagan and Libod, Tigaon, Camarines Sur through Community-Based Participatory Action Research approach. The result of the study will serve as baseline information to develop communitymanaged agritourism trek in the area to help the community uplift the socio-economic status. The study focuses on classifying the potential agritourism sites from the point of origin, accessibility, mode of transportation and side attractions, evaluating the environment and surroundings of the locality and other services. The Tourism Assessment Process (Linking Communities Tourism and Conversation) model was utilized through focused group discussions, ocular and site visit, and oral interview were considered in gathering the data. The gathered data were treated using descriptive statistics. Findings show that the Barangays of Libod and Tinawagan of Tigaon, Camarines Sur was found to have potential and prospects of agritourism sites, namely: Canibag Falls, Sanoy Farm, VK Farm, Helen's Haven, Señorita farm, centennial tree and Maripas Farm along location, distance, side attractions and classified as natural attraction and recreational activities. In terms of accessibility, potential markets, means of transport, and mode of transportation was perceived to be present in all the agritourism sites. While in terms of environment and surroundings it was revealed that potential agritourism sites along air quality has the highest weighted mean of 5.0 while the least was transportation with a weighted mean of 2.2. This means that the potential agritourism sites is free from pollution, tourists may enjoy the freshness of air and scenery of the locality, while in terms of basic services, it was found out that there is a source of water, transportation by any mean, communication maybe either globe or smart, compost fit for sewages and electricity. However, there is a problem on accommodation as noted in this study having only one establishment offering lodging accommodation but there are some members of the community offered a homestay service. Based on the result of the study which is limited to, this study recommends that the local government unit might consider in aid of legislation recognizing the potential agritourism sites, namely: Canibag Falls, Sanoy Farm, VK Farm, Helen's Haven, Señorita farm, centennial tree and Maripas Farm. Likewise, various infrastructure projects including road network rehabilitation, funding livelihood projects, etc. to showcase farm to table products and other development programs.

Keywords: agritourism, development, tourism potentials, community based participatory action research.

Author: Hospitality Management Department Partido State University San Jose Campus Del Carmen, San Jose, Camarines Sur 4423, Philippines. e-mails: jbromero_psu@gmail.com,

jossie.romero@parsu.edu.ph

\section{INTRODUCTION}

The potentials and prospects of agritourism sites drive its locality of becoming competitive and uplifting the socio-economic condition of the community. Tourism as one of the fast growing industry that creates enterprise opportunities to local folks and in adherence to the 10 point socio-economic agenda of President Duterte's administration to encourage both private and public individuals for rural and value chain development by increasing rural enterprise productivity. The local government unit drives to give the basic services to constituents and will include tourism development, tourism facilities and other tourist attractions.

Assessing Agritourism sites is vital in uplifting the economic development of a particular locality. This is to involve the community in the process, hence, their inputs is incorporated and significantly important in its desire to leverage their income. Agri-tourism is an innovative way of transforming the local farms to a place beneficial to everyone where activities for leisure and engaging other processing experiences is a stake. Developing the area into an agritourism destinations will contribute to its preservation and sustainability of potential sites. This will also protect the mother earth from ruining out and dangers. It provides additional income to local farmers that makes a difference between profit and loss of agricultural producers (Maetzold, 2002.) It also creates local jobs in the locality in delivering the basic goods and services to tourists.

The Philippine geographical locations surrounded with mountainous, agricultural lands and bodies of water creates a great opportunity to transform and enrich the agricultural sector into a tourist attractions which is strengthen by Republic Act 9538 stating the declaration of tourism policies and standards that supports the economy growth. Part of the involvement of the community is to strengthen the onfarm experience with the facilities used from traditional to modern technology. It will also serves as a gate way to invite tourists aside from the basic products taken from farm to table. The culture being facilitated with creativity sustains the anchored tourist experiences and invites more tourist to come and visit the place. Agri- 
tourism is a strategy to deliver the farmers good and products suited to tourist needs and wants.

The municipality of Tigaon belongs to 3rd class level in the province of Camarines Sur comprises of 23 barangays with 48,611 total population as per record at the Philippine Statistics Office. The main sources of living of the people in this municipality are corns, rice, sugar cane and abaca owned and managed by farmers. Local farmers in this locality adopts the emerging strategies to enrich their farm products. One among the farms present in the area transforms and used organic farming for chicken (organic) to eggs and other live stocks where the owner devices and used organic materials in producing organic products. Likewise, the plantation of the herbs and spices, fruit bearing trees, pineapple, green and leafy vegetables and other root crops are alternative ways used by farmers during off season.

Sitio Libod of Barangay Tinawagan, Tigaon, Camarines Sur was strengthened in June 22, 1963 through Republic Act 3590 "known as the revised barrio chapter" which resulted to the declaration of Sitio Libod into Barangay Libod, an additional Barangay in Tigaon, Camarines Sur with a total land area of $861.1632 \mathrm{Ha}$., situated in the northern part of Barangay Gaao, Southern part of Barangay Panagan, Eastern Part of Barangay Tinawagan and Western part of Barangay Consocep. This comprises of residential and agricultural area presently occupied by 450 households with 480 families dominated by Roman Catholic. The economic activity in the area was 90\% farming, 6\% Business and $4 \%$ Employment. This data manifested that agriculture is the prime source of income of the constituents, thus, valuing the farmers creativity in sustaining their products, this study is being conducted to evaluate the potentials and prospects of agritourism sites.

It was in this context that the community participation is ardently needed to participate in gathering information, consultations, group discussions, guides in the ocular site visits, enjoins all activities being conducted such as getting the approximate distance from one prospects to another, approximate time of arrival from one point to another were some of the basic involvement of the community. The participation of the community signifies a vital role in the process of this study to produce a factual and comprehensive data that will be used in crafting and evaluating the potentials and prospects of agritourism sites in the locality. This study aims to identify and classify the potentials and prospects of agritourism sites. Describe the possible distance from the point of origin to the prospect agritourism sites. It will also include the distance from one destination to another agritourism site and side attractions. This may be located along the road, or any strategic place that tourist could easily appreciate. It will also determine the available and easy way to access the area, the possible market, and the utilities available in the area. It will also Evaluate the potential agritourism sites along environment and surroundings, and basic services such as electricity, accommodation, water supply, means of communication and mode of transportation.. The results of this study will serve as baseline information in developing the communitymanaged agritourism sites in Barangays Tinawagan and Libod, Tigaon, Camarines Sur that aims to strengthen the agritourism sector of Partido.

\section{il. Materials and Methods}

\section{a) Respondents}

The respondents of the study were the barangay officials, representatives from Indigenous people and the community.

\section{b) Research Design}

The study used the Community Based Participatory Action Research approach in gathering factual data. The Tourism Assessment Process (Linking Communities Tourism and Conversation) model was utilized through focused group discussions, ocular and site visit, and oral interview to local folks and owners of potential agritourism sites were considered in gathering the data. To analyze the result and enable to have a clearer and better understanding descriptive statistics was employed.

\section{c) Collection and Gathering of Procedure}

The study used worksheets translated into dialect to easily facilitate the conduct of the focus group discussions. There were four (4) worksheets developed in gathering the data. The focus group discussion were attended by barangay officials headed by Barangay Captain, the Indigenous People headed by their Chieftain and members, the Womens organization with members, Barangay Tanods, Barangay Health Workers, Habal-Habal drivers. Ocular visit and unstructured interview were also conducted. 


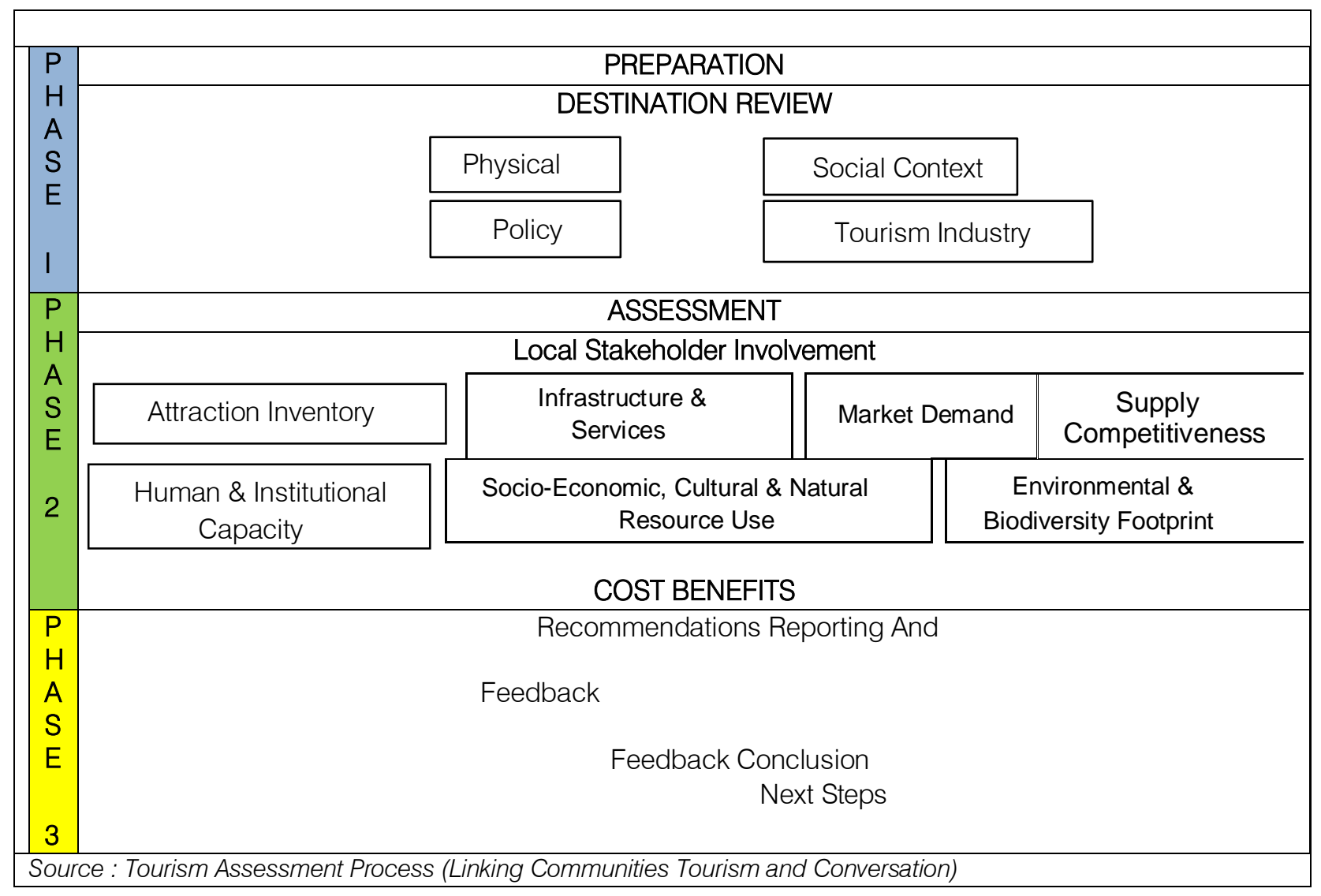

The Tourism Assessment Process (linking Communities Tourism and Conversation) model was utilized as a guide in involving the community in the process of developing the project. The needed variables was determined based on the model.

\section{ili. Results And Discussion}

\section{a) The classification of potential and prospects agritourism sites}

Table 1 presents the classification of potential agritourism sites in terms of attractions, location and features. Based on the results, it was revealed that these potential agritourism sites are classified as natural attractions and for recreational activities, namely: 1.) Canibag falls, 2.): VK Farm, 3.) Helen's Havens, 4.) Portion of Mt Isarog Natural Park, 5.) Sanoy Farm, 6.) Maripas Farm, 7. Centennial tree (matan tree), 8. Libod Elementary School-senorita (variety of banana) along location, distance and side attractions. It was found to have plantations, such as corn, banana, rootcrops, coconut, variety of trees, fruit bearing trees that tourist love to visit, pick and buy with the least area has an approximate size of $1 / 2$ hectares. It was noted that natural attractions such as Canibag Falls and centennial tree can be developed as highlight on agritourism trek to be visited considering the features with slope area, hillsides and rocky landscapes. Thus, this study is similar to the study on developed plantations in Virginia USA such as pumpkins, flowers, melon, orange and the like were visited by tourists. They picked what they want and pay before they leave. Tourists enjoy picking up pumpkins while in other rare area farmers innovates a cart where farm products are in place while in the Philippines we also experienced having the same plantations of flowers and vegetables in Cordillera region, likewise, agritourism destination was also developed in Davao with leisure activities for tourist. 
Table 1: Classification of Potentials and Prospects of agritourism sites

\begin{tabular}{|c|c|c|c|}
\hline $\begin{array}{l}\text { Indica } \\
\text { tors }\end{array}$ & Location & $\begin{array}{l}\text { Classification } \\
\text { of Attractions }\end{array}$ & Featurs \\
\hline 1. VK Farm & $\begin{array}{l}\text { Libod, Tigaon, } \\
\text { Camarines Sur }\end{array}$ & $\begin{array}{l}\text { Natural Attraction, } \\
\text { Recreational } \\
\text { Activities }\end{array}$ & $\begin{array}{l}\text { 3Ha incl. of herbs and spices, rootcrops } \\
\text { (cassava, carrots, etc,) vegetables(pechay, bitter } \\
\text { gourd, etc) } \\
\text { generate certified seeds, coconuts, lemon, corn- } \\
\text { using organic fertilizer }\end{array}$ \\
\hline $\begin{array}{l}\text { 2. Helens } \\
\text { Havens }\end{array}$ & $\begin{array}{l}\text { Libod, Tigaon, } \\
\text { Camarines Sur }\end{array}$ & $\begin{array}{c}\text { Natural Attraction, } \\
\text { Recreational } \\
\text { Activities }\end{array}$ & $\begin{array}{c}\text { 3Ha (incl. pool site, varieties of trees, fruit } \\
\text { bearing trees, pineapple plantation, tree house, } \\
\text { man-made } \\
\text { cave) }\end{array}$ \\
\hline $\begin{array}{l}\text { 3. Sanoy } \\
\text { farm }\end{array}$ & $\begin{array}{l}\text { Libod, Tigaon, } \\
\text { Camarines Sur }\end{array}$ & $\begin{array}{c}\text { Natural Attraction, } \\
\text { Recreational } \\
\text { Activities }\end{array}$ & $\begin{array}{c}\text { More than } 10 \mathrm{Ha} \text { (corn, banana, abaca, } \\
\text { rootcrops }\end{array}$ \\
\hline $\begin{array}{l}\text { 4. Maripas } \\
\text { Farm }\end{array}$ & $\begin{array}{l}\text { Tinawagan, } \\
\text { Tigaon, } \\
\text { Camarines } \\
\text { Sur }\end{array}$ & $\begin{array}{c}\text { Natural Attraction, } \\
\text { Recreational } \\
\text { Activities }\end{array}$ & Coconut, corn, cows, carabaos, chicken \\
\hline $\begin{array}{l}\text { 5. Canibag } \\
\text { Falls }\end{array}$ & $\begin{array}{l}\text { Libod, Tigaon, } \\
\text { Camarines Sur }\end{array}$ & $\begin{array}{c}\text { Natural Attraction, } \\
\text { Recreational } \\
\text { Activities }\end{array}$ & $\begin{array}{l}\text { Slope area, hillsides, rocky } \\
\text { landscapes, water falls }\end{array}$ \\
\hline $\begin{array}{l}\text { 6. Centennial } \\
\text { Tree }\end{array}$ & $\begin{array}{l}\text { Libod, Tigaon, } \\
\text { Camarines Sur }\end{array}$ & $\begin{array}{c}\text { Natural Attractions, } \\
\text { Recreational } \\
\text { Activities }\end{array}$ & $\begin{array}{c}\text { About } 5 \mathrm{~m} \text {. in diameter, approx..2kms with slope } \\
\text { area away from Libod Centro }\end{array}$ \\
\hline $\begin{array}{l}\text { 7. Senorita } \\
\text { Plantation }\end{array}$ & $\begin{array}{l}\text { Libod, Tigaon, } \\
\text { Camarines Sur }\end{array}$ & $\begin{array}{l}\text { Natural } \\
\text { Attractions, } \\
\text { recreational } \\
\text { Activities }\end{array}$ & $\begin{array}{c}\text { Appro.1/2Ha. Approx.. } 300 \text { meters away from } \\
\text { Barangay Hall of Libod }\end{array}$ \\
\hline $\begin{array}{l}\text { 8.Pineapple } \\
\text { plantation }\end{array}$ & $\begin{array}{l}\text { Libod, Tigaon, } \\
\text { Camarines Sur }\end{array}$ & $\begin{array}{c}\text { Natural } \\
\text { Attractions }\end{array}$ & Approx. $1 \mathrm{Ha}$. \\
\hline
\end{tabular}

b) Describe the potential agritourism sites terms of: a) distance from the point of origin to prospect agritourism sites and side attractions; and b) potential accessibility, potential market, means of transport, and mode of transportation

Table 2A: Agritourism Potential and Prospects: Name, Distance and Side Attractions

\begin{tabular}{|c|c|c|}
\hline Potential Attractions & Distane & Side Attractions \\
\hline 1.Canibag Falls & $\begin{array}{lrr}\text { Approx.. } & 1.5 \mathrm{kls} & \text { From } \\
\text { Centro Libod } & \text { to } \\
\text { destination } & \\
\text { Tigaon-Centro Libod } & 7 \mathrm{kms}\end{array}$ & $\begin{array}{l}\text { Corn plantation (approx.. } \\
20 \mathrm{Ha} \text {, ) } \\
\text { Banana (approx.. } 4 \mathrm{Ha} \\
\text { Abaca }(1 \mathrm{Ha}) \\
\text { Coconut (2ha) } \\
\end{array}$ \\
\hline 2.VK Farm & $\begin{array}{l}\text { Approx.. Tigaon- } 5.2 \mathrm{kms} \\
\text { VK farms-Libod Centro } 1.8 \mathrm{kms} \\
\text { Approx. } 300 \text { meters from the main } \\
\text { road of Barangay Libod Road }\end{array}$ & $\begin{array}{l}\text { Poultry Farm Corn } \\
\text { Plantation Herbs } \\
\text { and spices } \\
\text { Flowering plants } \\
\text { Fruit bearing trees } \\
\text { WildPigs }\end{array}$ \\
\hline
\end{tabular}




\begin{tabular}{|c|c|c|}
\hline 3. Helen Havens & $\begin{array}{l}\text { Approx..Tigaon-Centro Libod } \\
7 \mathrm{Kms} \\
\text { Centro-Haven's 400mtrs }\end{array}$ & $\begin{array}{l}\text { Man-made cave Fruit } \\
\text { bearing trees Tree } \\
\text { house Pineapple } \\
\text { plantation Assorted } \\
\text { trees Lodging house } \\
\text { Cottages } \\
\text { Swimming pool } \\
\text { Proposed EcoPark }\end{array}$ \\
\hline $\begin{array}{l}\text { 4.Mt. Isarog Natural Park } \\
\text { (Provincial) } \\
\text { Hiking }\end{array}$ & Centro Libod - 3kms & $\begin{array}{l}\text { Corn plantation (approx.. } \\
20 \mathrm{Ha} \text { ) } \\
\text { Banana (approx.. } 4 \mathrm{Ha} \\
\text { Abaca }(1 \mathrm{Ha} \text { ) } \\
\text { Coconut (2ha }\end{array}$ \\
\hline 5.Sanoy Farm & $\begin{array}{l}\text { Libod centro to hillside area of Mt. } \\
\text { Isarog }\end{array}$ & $\begin{array}{l}\text { Corn plantation (approx.. } \\
\text { 20Ha,) } \\
\text { Banana (approx.. } 4 \mathrm{Ha} \\
\text { Abaca }(1 \mathrm{Ha}) \\
\text { Coconut (2ha }\end{array}$ \\
\hline 6.Maripas Farm & $\begin{array}{l}\text { Approx. Tinawagan Centro to } \\
\text { hillside of Mt Isarog } 2.5 \mathrm{kms}\end{array}$ & $\begin{array}{l}\text { Spillway, corn plantation, } \\
\text { banana, abaca }\end{array}$ \\
\hline $\begin{array}{l}\text { 7.Centennial tree } \\
\text { approx. } 5 \mathrm{mtr} \text { in dia. } \\
\text { (Matan tree) house--- } \\
\text { BAT }\end{array}$ & Centro-libod 2kms & Corn, abaca \\
\hline $\begin{array}{l}\text { 8.Elementary school - } \\
\text { senorita (inarnibal) }\end{array}$ & Centro-Brgy. Libod & Libod Elementary School \\
\hline
\end{tabular}

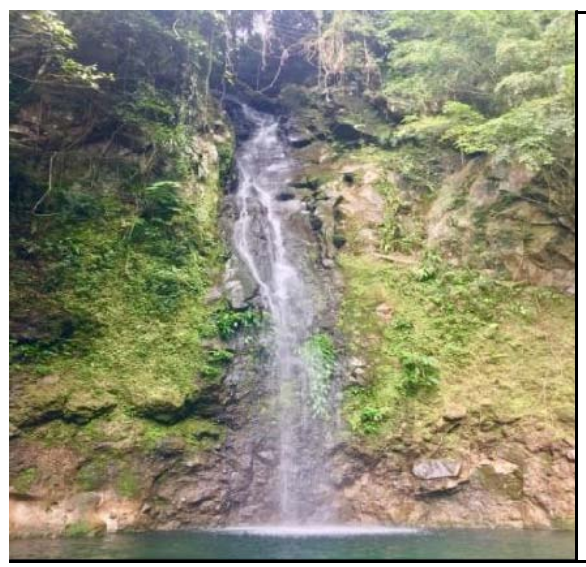

The Canibag Falls has an approximate height of 40 meters. According to the local folks of the area, the name Canibag was taken from the shape of the falls like a bag with the canal like - a passage way of the water, the nature attractions enriches with the flora and fauna, different vine trees and shaped rocks.

Canibag Falls is approximately $1.5 \mathrm{kms}$ from Centro of Barangay Libod with an approximate time of 45 mins. walking. There are hillsides and riverbanks, variety of rock formations along the sides. While Sanoy Farm is the gateway to Canibag Falls. (results taken from ocular visit and interview)

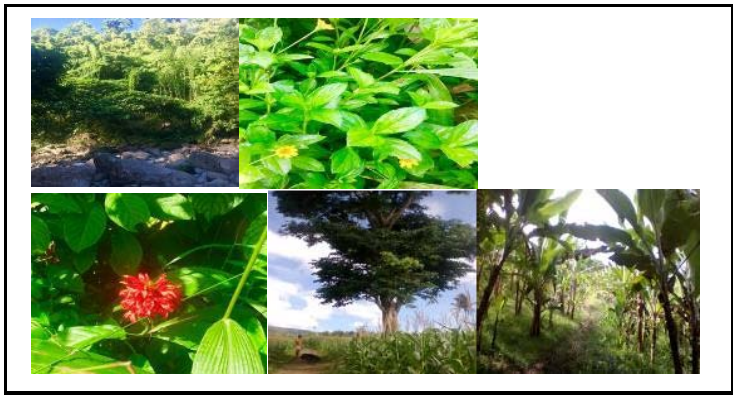

Sanoy Farm is the gateway going to Canibag Falls, centennial tree and Mt Isarog Natural Park. It is located at Libod, Tigaon, Camarines Sur. Farm produced products are corn, banana, abaca, jackfruit, cassava, coconut, etc. It has an approximate land area of more or less $10 \mathrm{Ha}$. Sanoy Farm is owned and managed by Mr. Saturnino Sanoy. (results taken from ocular visit and interview) 


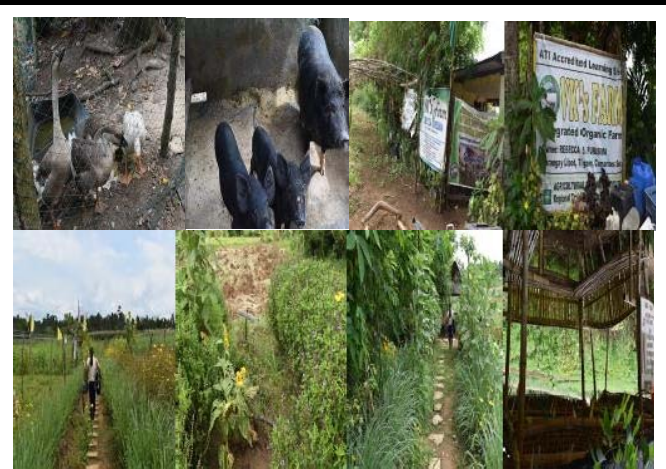

VK Farm is located at Barangay Libod, Tigaon, Camarines Sur. The project-based organic farming was known for having herbs and spices, corn, rice, coconut, vegetables, etc. It is also the placed certified for producing variety of seeds being collected by the Department of Agriculture. VK farm is approximately 400 meters away from the main road of Barangay Libod owned by Veronica Purisima. (results taken from ocular visit and interview)

Helen's Havens is approximately 400 meters away from the Barangay hall of Libod. Side attractions were the fruit bearing trees along its entrance side by side, man-made cave, variety of trees, the tree house, the proposed eco-park, pineapple plantation. There are cottages and lodging room for family with the unique swimming pool that children love to swim and play. Plantation of senorita banana plants were located at Libod Elementary School, serves also as the gateway to Helen's Havens owned and managed by Mr. and Mrs. Joseph Mendoza. (results taken from ocular visit and interview)

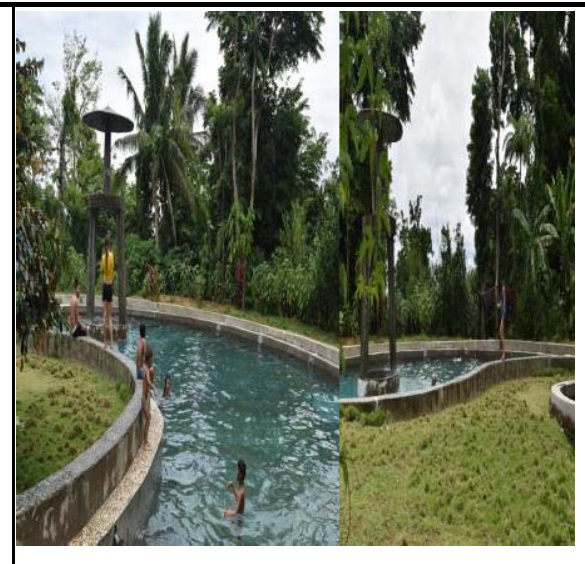

Maripas farm is located in Tinawagan, Tigaon, Camarines Sur. This serves as the training area for farmers. There are more or less 40 cows and 6 carabaos in the area dominated by coconut trees. There are hills and slope at Maripas farm approximately $2.5 \mathrm{kms}$ away Tinawagan Centro. (results taken from ocular visit and interview)

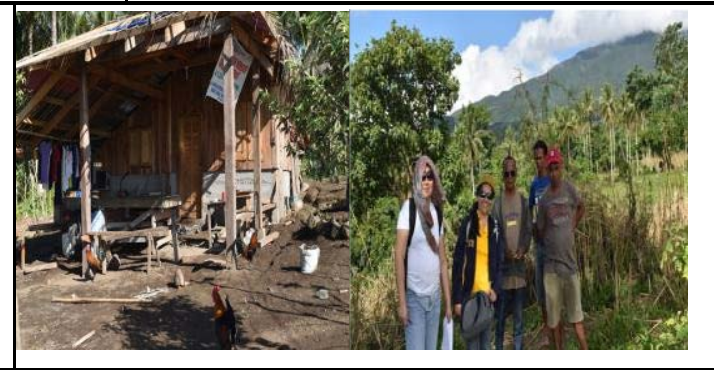

Globally, tourists travel from one place to another for leisure, pleasure and business. Some tourist loved to visit farms enjoying and picking farm products and placed it on the table. They loved the freshness of the farm produced products. In United States, agritourism is part of the working agribusiness their area while in the Philippines, Luzon's Cordillera Administrative Region, is the prime agri-tourism destination of the country. Likewise, the Department of Agriculture and
Bureau of Soils and Water Management in Davao also conceptualized a program called agritourism that aims of attracting tourists to observe and experience the unique Filipino Agriculture and rural living as well as a means of maximizing the agricultural potential of an area. Based on their concepts Agritourism can alleviate poverty and increase agricultural productivity, sustaining development and dispersing industries.

Table 2B: Potentials and Prospects: Accessibility, Potential Markets, Means of transport, Mode of Transportation

\begin{tabular}{|l|c|l|l|l|l|c|}
\hline Location & $\begin{array}{c}\text { EASY } \\
\text { (up to 1hr } \\
\text { walk) }\end{array}$ & $\begin{array}{c}\text { MODERATE } \\
\text { (hills 1-2hrs) }\end{array}$ & $\begin{array}{c}\text { DIFFICULT } \\
\text { (Step climbs2 } \\
\text { thrs) }\end{array}$ & $\begin{array}{c}\text { Potential } \\
\text { Market }\end{array}$ & $\begin{array}{c}\text { Means } \\
\text { of } \\
\text { transprt }\end{array}$ & $\begin{array}{c}\text { Mode of } \\
\text { transportation }\end{array}$ \\
\hline $\begin{array}{l}\text { Canibag } \\
\text { Falls }\end{array}$ & $/$ & & & Weekender & Anytime & Walking \\
\hline VK Farm & 1 & & Day Trip & Anytime & PUV \\
\hline $\begin{array}{l}\text { Helen } \\
\text { Have } \\
\text { ns }\end{array}$ & $/$ & & Day Trip & Anytime & PUV \\
\hline
\end{tabular}




\begin{tabular}{|c|c|c|c|c|c|c|}
\hline $\begin{array}{l}\text { Mt. } \\
\text { Isarog } \\
\text { Natural } \\
\text { Park } \\
\text { (Provincial) }\end{array}$ & & & i & Long Stay & Scheduled & Walking \\
\hline $\begin{array}{l}\text { San } \\
\text { oy Farm }\end{array}$ & I & & & Day trip & Anytime & PUV \\
\hline $\begin{array}{l}\text { Maripas } \\
\text { Farm }\end{array}$ & & I & & weekender & None & PUV/walking \\
\hline $\begin{array}{l}\text { Centenni } \\
\text { al tree } \\
\text { approx.. } \\
5 \mathrm{mtr} . \text { in } \\
\text { dia. } \\
\text { (Matan } \\
\text { tree) } \\
\text { house-- BAT }\end{array}$ & & & 1 & Long stay & Scheduled & PUV/walking \\
\hline $\begin{array}{l}\text { Elementar } \\
\text { y school - } \\
\text { senorita } \\
\text { (inarnibal) }\end{array}$ & l & & & Day trip & Anytime & PUV \\
\hline
\end{tabular}

Table 2B presents the potentials and prospects along accessibility, potential market, means of transport and mode of transportation. It was noted that VK Farm, Helen's Havens, Sanoy Farm and Senorita plantation could easily be reached within an hour to travel, likewise, Canibag falls needs to consider the weather condition of the area due to hillsides and riversides while the most difficult to access were the Mt. Isarog natural park and centennial tree. In terms of potential market, VK Farm, Helen's Havens, Sanoy Farm and Senorita plantation were for day trip while Canibag Falls during weekender. However, centennial tree and Mt. Isarog will be on a long stay. The means of transport in this study pertains to the number of days that the guest may spent before the area will be reach. Based on the results, these potentials and prospects of agritourism sites in Barangays Libod and Tinawagan can easily be reach with a day while the mode of transportation was any kind of vehicle, could reach the perspective destinations, however at present the commonly used mode of transportation is the Habalhabal. This means that there is an urgent need to priority the development of the locality along infrastructure and means of transportation. Likewise, this is similar to the study of S.H.P. Malkanthi and J.K. Routry, (2011) that presents possibilities of establishing agritourism in Sri Lanka which this study consider in the process of conducting this study. Wherein based on their studies it is essential in the development of a successful agritourism is the infrastructure development that would improve the economic, social, cultural and aesthetic level of the areas.

c) Evaluate the potential agritourism sites in terms of: a) environment and surroundings, and b. basic services

Table 3A: Environment and Surroundings

\begin{tabular}{|l|c|c|c|c|c|c|}
\hline \multicolumn{1}{|c|}{ Indicator } & $\begin{array}{c}\text { VK } \\
\text { Farm }\end{array}$ & $\begin{array}{c}\text { Helen's } \\
\text { Haven }\end{array}$ & $\begin{array}{c}\text { Maripas } \\
\text { Farm }\end{array}$ & $\begin{array}{c}\text { Sanoy } \\
\text { Farm }\end{array}$ & $\begin{array}{c}\text { Senorita } \\
\text { Farm }\end{array}$ & $\begin{array}{c}\text { Weighted } \\
\text { Mean }\end{array}$ \\
\hline 1. Air Quality & 5 & 5 & 5 & 5 & 5 & 5.0 \\
\hline 2. road network & 4 & 4 & 2 & 4 & 4 & 3.6 \\
\hline 3.communication & 3 & 3 & 2 & 3 & 3 & 2.8 \\
\hline 4. transportation & 3 & 3 & 1 & 3 & 3 & 2.2 \\
\hline 5. water sources & 4 & 4 & 3 & 4 & 4 & 3.8 \\
\hline 6. Side Attractions & 3 & 3 & 3 & 3 & 3 & 3.0 \\
\hline
\end{tabular}

Legend: Perception used that scale from 1-5, where 5 is excellent, 4 very, satisfactory, 3 satisfactory, 2 fair, 1 poor 
In terms of environment and surroundings, table $3 \mathrm{~A}$ reveals that potential agritourism sites along air quality has the highest weighted mean of 5.0 while the least was transportation with a weighted mean of 2.2 as perceived by the community. This means that the potential agritourism sites is free from pollution, tourists may enjoy the freshness of air and scenery of the locality. However, there is a problem along transportation if the tourist doesn't have his/her own car considering that at present the only mean of transportation in the area is Habal-habal, which is also followed by communication that internet is unstable which this study was supported by the study of Eckert, that according to him family farms usually faced serious challenged on economic side and competition with the large corporate farms.

In terms of basic services, table 3B shows the perception of the community that potential agritourism sites found to have the source of water, transportation by any mean, electricity in some figures or area necessary and composed fit where they placed their sewages, However, there is a problem on accommodation as noted in this study having only one offering lodging accommodation.

Table 3B: Basic Services

\begin{tabular}{|l|c|c|c|c|c|c|}
\hline Indicators & Electricity & Water & Accommodation & Communication & Transportation & Sewages \\
\hline 1. VK Farm & $/$ & $/$ & $\mathrm{X}$ & Globe/smart & PUV & Composedpit \\
\hline $\begin{array}{c}\text { 2. Helens } \\
\text { Havens }\end{array}$ & $/$ & $/$ & $/$ & Globe/smart & PUV & Composedpit \\
\hline 3. Sanoy farm & $/$ & $/$ & $\mathrm{X}$ & Globe/smart & PUV & Composedpit \\
\hline 4. Maripas Farn & $/$ & $/$ & $\mathrm{X}$ & Globe/smart & PUV & Composepit \\
\hline 5. Canibag Fall & $\mathrm{X}$ & $/$ & $\mathrm{X}$ & Globe/smart & PUV & Composedpit \\
\hline $\begin{array}{l}\text { 6.Centenni } \\
\text { al Tree }\end{array}$ & $\mathrm{X}$ & $/$ & $\mathrm{X}$ & Globe/smart & PUV & Composedpit \\
\hline $\begin{array}{l}\text { 7. Senorita } \\
\text { Plantation }\end{array}$ & $\mathrm{X}$ & $/$ & $\mathrm{X}$ & Globe/smart & PUV & Composedpit \\
\hline $\begin{array}{c}\text { 8. Pineapple } \\
\text { plantation }\end{array}$ & $\mathrm{X}$ & $/$ & $\mathrm{X}$ & Globe/smart & PUV & Composedpit \\
\hline
\end{tabular}

\section{Conclusion}

It is concluded that VK Farm, Helen's Havens, Sanoy Farm, Senorita plantation, Pine apple plantation and Canibag Falls are potentials and prospects for agritourism sites at Barangays Libod and Maripas Farm in Tinawagan, Tigaon, Camarines Sur. These potential agritourism sites needs to be developed with infrastructure to become more responsive to tourist.

\section{Recommendations}

It is therefore recommended that the local government unit might consider to make the necessary policies and guidelines, recognizing the identified as agritourism sites as potential agritourism destinations of the locality where people could visit, experience the scenery on manual planting of corn, banana, pineapple, cassava and harvesting or picking up the same for a fee.

It is likewise recommended to priority infrastructure projects in the area such as road network and construction of livelihood building that people could use to showcase their farm products.
Further, this study serves as a baseline information for the development of the community managed agritourism trek in Barangays Libod and Tinawagan, Tigaon, Camarines Sur and in aid of legislation for agritourism projects. Moreover, further studies on the market demand and socio-economic status, marketing strategies and biodiversity.

\section{ACKNOWLEDGMENT}

The author acknowledges its funding institution -the Research and Development Council of Partido State University for financial and technical support. Likewise, to the respondents of the study whose supported in the entire data gathering.

Conflict of Interest

The author declares no conflict of interest.

\section{References Références Referencias}

1. Agriculture Magazine, Agri-tourism Aspects, Manila Bulletin Publishing Corp. Muralla Corner Recoletes St. Intramuros Manila January 2014, pp.34-38. 
2. Barbieri, C., 2012. Assessing the Sustainability of Agritourism in the US: a Comparison between Agritourism and other Farm entrepreneurial ventures, Journal of Sustainable Tourism, Department of Parks, Recreation and Tourism School of Natural Resources, University of Missouri, 105 Anheuser-Busch Natural Resources Building, Columbia, Missouri, 65211, USA, 21:2, 257-270.

3. Basiago, A.D. 1999. The Environmentalist 19, Kluwer Academic Publishers, Boston, pp. 145-161.

4. Cooper, C and Hall, C. M., 2013. Contemporary Tourism: An International Approach, Second edition, Good fellow Publishers Ltd, Woodeaton, Oxford, OX3 9T, UK, pp.107 \& 195.

5. Deepalngavale, 2015. Agri Tourism- A Business Model of Agri Tourism Development Corporation, PARIPEX-Indian Journal of Research, Vol 4, Issue 1.

6. Guidelines for Environmental Infection Control in Health-Care Facilities, 2003, GA Atlanta.

7. Maetzold, J. A. 2002. Nature-Based Tourism \& Agritourism Trends: Unlimited Opportunities, National Alternative Enterprises and Agritourism Leader, USDA/NRCS, Washington, DC pp.84.

8. Malkanthi S. H. P. and Routry, J. K., 2011. Potential for Agritourism Development: Evidence from Sri Lanka, The Journal of Agricultural Sciences, Vol. 6, No.1.

9. Managing Protected Areas, A Global Guide, 2006, IUCN, USA, pp 497-498.

10. Manguni, K., 2010. The Socio-Economic Analysis of Agritourism in Two Rural Communities in the Limpopo Province, University of South Africa.

11. Message: Prof. Eli Paolo Fresnoza, Assistant Professor at UP's Asian Institute of Tourism during SEARCA's Agriculture and Development Seminar Series on 5 July 2011 at the Drilon Hall.

12. Nikolopoulou, Anastasia, et. al., 2010. Education for Sustainable Development, Challenges, strategies, and Practices in a Globalizing World, SAGE Publications, India Pvt Ltd, 2010.

13. Ohe, Y. and Ciani, A. 2012. Accessing Demand Characteristics of Agritourism in Italy, Journal on Tourism and Hospitality Management Vol 18, No. 3.

14. Omann, I and Spanggenberg, J. H. Assessing Social Sustainability, Sustainable Europe Research Institute (SERI) Schwarzspanierstr, 4/7, A-1090 Wien, Austria.

15. Phandee, M and Pornpatchara Pinthong, 2012. The Agricultural Areas Potentials Development for Agrotourism Using Geographic Information System, International Journal of Innovation, Management and Technology, Vol 3. No 6.

16. ROtl Handbook.pdf

17. Scheewe, W., 2000. An Introduction to Sustainable Agriculture, Nurturing the Soil-Feeding the People,
Rex Book Store, Inc. Santa Mesa Heights, Quezon City, Philippines, pp 119-120.

18. The UNHCR Tool for Participatory Assessment in Operations.

19. Zunic, L., 2011. The Impact of Agritourism on Sustainable Development of Bosnia and Herzegovina, p.p.109-120. 